Милош М. Ковачевић

Филолошки факултет у Београду

Филолошко-уметнички факултет у Крагујевцу

mkovacevic31@gmail.com

https://doi.org/10.18485/ai_gozik.2019.ch4

821.163.41.09

$811.163 .41 ' 38$

\title{
СТИЛИСТИЧКА ГОЗБА У КЫИЖЕВНОСТИ
}

Предмет рада ${ }^{1}$ је анализа теорије о књижевном стилу као избору између различитих могућности које свакоме говорнику, па сљедствено и свакоме писцу, језик ставља на располагање, с тим да те различите могућност избора представљају различите стилистичке варијанте. Та анализа за полазиште има теорију појмовне метафоре.

Показано је да се о стилу као умијећу изналажења изражајних средстава и стилистичких поступака, који су по правилу на неки начин девијантни у односу на изразе свакодневног језика - расправљало од античких времена до данас. Суштину теорије о стилу као избору одражавају три појмовне метафоре: 1) КЊИЖЕВНИ ТЕКСТ ЈЕ ГОЗБА, 2) ЈЕЗИК ЈЕ ТРПЕЗА и 3) КЊИЖЕВНИ ТЕКСТ ЈЕ УЖИТАК/УЖИВАЮЕ. Те три појмовне метафоре имплицитно потврђују да се књижевно дјело једино може схватити и анализирати као дијалектичко јединство ПИСЦА, ЈЕЗИКА и ЧИТАОЦА.

Кључне ријечи: књижевни текст, стилистика, појмовна метафора, гозба, избор, аутор, читалац.

Већ насловна синтагма „стилистичка гозба“ тематику нашега рада повезује с когнитивном лингвистиком,

1 Рад је урађен у оквиру пројекта 178014: Динамика структура савременог српског језика, који финансира Министарство просвете, науке и технолошког развоја Републике Србије. 
или прецизније речено њеним најзначајнијим дијелом: појмовном или концептуалном метафором. А централни појам у когнитивној лингвистици јесте појам конструкиије значена, који се „односи на човјекову способност да исту ситуацију види на различите начине“, подразумијевајући притом да „човјек може одабрати (свјесно или несвјесно) једно одређено између више значења“ (Šarić 2014: 13). Један од основних когнитивних процеса структурисања значења јесте концептуална или појмовна метафора (уп. Stanojević 2009; Klikovac 2004). У метафорском процесу увијек се повезују два когнитивна домена: изворни и циљни домен, при чему се циљни као апстрактнији домен разумијемо на основу тога што се на њ пресликавају подударни елементи конкретног изворног домена. Пресликавање тако омогућава да се на основу добро познатог изворног домена и његових елемената разумије мање познат или непознат циљни домен са својим елементима. (уп. Klikovac 2004:11-12; Stanojević 2009: 341-342; Šarić 2014: 14). У основи сваке појмовне метафоре тако стоји формула: ЦИЉНИ ДОМЕН ЈЕ ИЗВОРНИ ДОМЕН (Stanojević 2009: 341). Таква је, на примјер, појмовна метафора РАСПРАВА JЕ РАТ, гдје „појам рата структурира наше разумеване појма расправе, наше понашағе у њој и, најзад, ми о расправи говоримо користећи речи које се у свом основном значењу односе на рат“ (Klikovac 2004: 12; уп. и Stanojević 2009: 344). У појмовној метафори тако се сусрећу дословно и метафоричко значење, дословно које се односи на изворни домен и метафоричко које се односи на циљни домен, при чему „дословни и метафоричко значење имају исти значај“ (Stanojević 2009: 342). А „коцептуална метафора се као спознајна способност одражава у језику, што значи да разликујемо двије разине: метафорички језични израз и концептуалну метафору“ (Stanojević 2009: 340-341). 
Основни предмет нашега рада одражава се у структури доминантне појмовне метафоре: КЊИЖЕВНИ TЕКСТ ЈЕ ГОЗБА, која супсумира најмање двије појмовне метафоре: ЈЕЗИК ЈЕ ТРПЕЗА и КЊИЖЕВНИ ТЕКСТ ЈЕ УЖИТАК/УЖИВАҢЕ. За потврду наводимо неколико реченица из књижевнотеоријских текстова о књижевности или књижевном тексту:

(1) Сав би напор, напротив, био у томе да се ужитак у тексту материјализира, да се од текста створи предмет ужитка као што су други. (Barthes 2004: 148)

(2) Семиотичко читање текста ... оно не прописује начине на који у тексту треба уживати, него нам показује зашто текст може произвести уживаюе. (Eko 2015: 166)

(3) Може ли наслада (ужитак, задоволство) бити истински циљ умјетности (како су у његово вријеме, а и касније, мислили заступници естетичког хедонизма)? (Lešić 2015:53)

(4) По Платону, наслада (тј. ужитак), може бити само узгредно осјећање, „попратна појава“, а нипошто не и коначни циљ умјетности. (Lešić 2015:53)

(5) ...уметност је специфична форма кретања која уједињује творца дела и уживаоца дела (Pavlović 2018:68)

(6) Колриџ се слаже са Вордсвортом када он износи традиционално мишљење да је циљ поезије пружане задовольтва, ужитка (Doležel 2013: 105) 
Наведени (1)-(6) примјери су метафорички јер се у њима књижевност, односно књижевни текст описује као ГОЗБА, на што недвосмислено упућују истакнути изрази (ужитак, уживање, наслада, задовољство). Ти изрази се, међутим, не односе на ЈЕЛО као изворни домен него на КЊИЖЕВНИ ТЕКСТ као циљни домен. На тај начин наведене примјере (1) - (6) можемо свести на појмовну метафору КЊИЖЕВНИ ТЕКСТ ЈЕ ГОЗБА. Битно је нагласити да се анализа појмовне метафоре не односи само на пресликавање појединих дијелова изворног домена на циљни, него да подразумијева и „закључивање о појединим аспектима циљне домене на темељу закључка и знања о изворној домени“, јер се „на циљну домену не пресликавају сви ентитети из изворне домене него само неки“ (Станојевић 2009: 341-342). Због тога, „премда циљну домену устројавамо помоћу изворне домене, наша знања о својствима циљне домене ограничавају пресликавања и имају предност пред концептуалном метафором“ (Stanojević 2009: 345).

У случају појмовне мотефоре КЊИЖЕВНИ ТЕКСТ JЕ ГОЗБА, која је предмет нашег истраживања у овом раду, ГОЗБУ у њеном основном, неметафоричком значењу као „обилан илепо припремлен обед (ручак или вечера) участ гостију, свечаност, пријем са гошћенем, чашћаванем" (Речник 2007: 207) и ГОЗБУ у њеном метафоричком значењу као „писање и/или читање књижевног текста“ повезује „гозбеник“, јер ни у примарном ни у метафоричком значењу „гозбе“ нема без гозбеника. У рјечнику српскога језика гозбеник је двозначна ријеч, јер значи „онај који приређује гозбу; учесник у гозби“ (Речник 2007: 208). Гозбеник је, дакле, двоврстан: он је не само „приређивач гозбе“ него и „корисник гозбе“ (њен конзумент). Сличан је случај и са књижевношћу: јер ни у њој „гозбеник“ није једнозначан. Гозбеник може бити и/или писаи (произвођач књижевног текста) и/или читалаи (кори- 
сник, рецептор текста). Статус „гозбеника“тако имплицитно упућује на схватање књижевног дјела „као дијалектичког јединства трију димензија, димензије писца, димензије језика и димензије читаоца“ (Petrović 2009: 77). Између неметафоричке и метафоричке „гозбе“ може се уочити изоморфна трокомпонентна структура: „гозбеник јело - конзументи“ наспрам „писац - дјело - читаоци“. A „јело“ и књижевност или пак умјетност у цјелини већ су у књижевнотеоријској литератури довођени у везу преко начина дјеловања на „конзументе“, тј. гозбенике као уживаоце јела или књижевности, односно умјетности. Ту везу успоставио је у својим Законима Платон пропитујући тадашње готово општеприхваћено мишљење да се „права вриједност умјетности очитује у способности да душама пружи насладу“. Платон је сматрао да наслада или ужитак не може бити примарни циљ умјетности, него највише узгредно осјећање или пропратна појава:

Умјетност се, сматрао је Платон, не може процјењивати по наслади коју изазива, већ једино по ономе што је њој као умјетности примјерено. Као и иначе, Платонова мисао је и овдје прибјегла сликовитом поређењу: и јело прати угодност коју можемо назвати насладом, али вриједност јела није у уживању већ у ономе што је јелу примјерено, тј. у здрављу које долази с јелом; и учење може пратити угодност, али ни вриједност учења није у ужитку већ у ономе што је учењу примјерено, тј. у истини до које се учењем долази. Тако је, каже Платон, и с умјетношћу [...]. Ако је вриједност јела у здрављу, а вриједност учења у истини, вриједност умјетности је у љепоти, мислио је Платон, који је међу првима одлучно повезао појмове "умјетност“ и „љепота“" и први формулирао оно што ће много касније бити прихваћено као естетички аксиом: дјеловање умјетности је у конструирању љепоте, која као таква, као љепота, дјелује на оне који у умјетности уживају (естетско дјејство). (Lešić 2015:54-55). 
Чини се, међутим, да је, у интерпретативном поступку, адекватније направити поређење књижевности са трпезом или софром неголи са самим јелом, пошто трпеза или софра по својим особинама много боље него само јело кореспондирају са књижевним дјелом. Трпеза или софра је, наиме, презентовани ИЗБОР из јела, тако да представља својеврсни „шведски сто“. А појам ИЗБОРА директно упућује како на суштину језичке комуникације тако и на суштину комуникацијске природе књижевности. Јер ако је ТРПЕЗА избор из јела, онда је ВЕРБАЛНИ ЧИН избор из језика. Зато се суштински однос између писца и дјела остварује преко ЈЕЗИКА и заснива на појмовној матафори: ЈЕЗИК ЈЕ ТРПЕ3А. Као што је ТРПЕЗА за „гозбеника“ у оба значења (и као приређивача гозбе и као корисника гозбе) ИЗБОР, тако и ТРПЕЗА код књижевног дјела представља ИЗБОР и за писца и за читаоца.

Појам ИЗБОРА у књижевности директно асоцира једну од најзначајнијих стилистичких теорија у тумачењу суштине књижевног чина. Ту је теорија стила као избора језичких средстава, експлицитно инаугурисао франщуски стилистичар Жил Марузо (Lešić 1971; Majenova 2009: 338) тврдећи да је језик „репертоар могућности, заједнички фонд који корисницима стоји на располагању и из њега, према својим потребама, црпу експресије, вршећи избор, тј. стварајући стил, у оквирима које допуштају закони језика“" (Majenova 2009: 338).

Језичка комуникација подразумијева двије врсте поступака као двије врсте избора: селекиију $u$ комбинацију. Селекција или парадигматски однос представља избор између елемената система који се могу међусобно замјењивати, док комбинација или синтагматски однос подразумијева комбинаторне могућности између елемената добијених селекцијом. Цјелокупни се језички систем, по де Сосировом мишљењу, 
„може свести на теорију синтагматских и парадигматских односа и објаснити на основу њих“ (Kaler 1980: 58). Зато темељни принцип који важи за језичку комуникацију уопште мора важити и за књижевну комуникацију, будући да је књижевност вербална умјетност. Те различите могућности које свакоме говорнику, па сљедствено и свакоме писцу, језик ставља на располагање П. Гиро је назвао стилистичким варијантама (Giro 1964: 37). Теорија стила као избора подразумијева да „стил живи од варијаната: исто стање ствари можемо изразити у више варијаната употребом разноврсних а међусобно замењивих језичких знакова који су на располагању у језичком коду“ (Juvan 2011: 193).

Како се критеријум избора може примијенити у анализи књижевног дјела, експлицитно је показао 3. Лешић анализом једног Шантићевог стиха из пјесме „Вече на шкољу“. Указујући на опште важење стилистичког принципа избора између различитих варијаната у анализи књижевног дјела, 3. Лешић ће написати да:

чак и онако јединствен и непоновљив језички израз као што је Шантићев стих Пучина плава спава није ништа друго до резултат једног процеса који се може описати као селекиија сличних језичких елемената на парадигматском низу и њихова комбинација према блискости и повезаности на синтагматском низу. Можемо претпоставити да се тај процес извршио на основу ових могућности којим располаже наш језик:

$\begin{array}{llc}\text { плаво } & \text { море } & \text { мирно је } \\ \text { модро } & \text { морска површина } & \text { мирује } \\ \text { сиње } & \text { пучина } & \text { почива }\end{array}$

спава

Вертикални низови су парадигматски, засновани на сличности по значењу, хоризонтални низови су синтагматски, засновани на могућности повезивања у синтагме и реченице. Селекцијом у једном и комбинацијом у дру- 
гом низу, у једном процесу колико симултаном толико и инстинктивном, остварила се једна од бројних могућности: „Пучина плава спава“. Истовремено, та остварена могућност представља се у односу на све друге као посебна. Иако чува основну количину значења које садржавају и све друге, неостварене могућности (а стварно је изненађујуће мала семантичка разлика међу њима), Шантићев стих се бар у три аспекта разликује од других могућих варијанти. Прво, алитерације консонанта $n$, који се појављује у све три ријечи стиха, уједињује елементе израза у цјеловит и формално кохерентан језички израз, а добијена асонанца плава спава остварује један самостални музички валер, који друге комбинације не би имале и који јесте стварни разлог оваквог груписања ријечи. Тиме се потврђује естетска функција самог израза, који на тај начин превазилази чисту комуникацију. Друго, избор ријечи 'спава' придаје миру мора једну нијансу људског значења: да ли неког угодног умора?, или неке безбрижне одсутности?, или неког тајног сна? то је на нама да свако за себе одлучи, али се управо тиме потврђује стваралачка способност пјесника да ријечима in praesentia доведе у нашу свијест појмове in absentia, остварујући једну асоцијативну координацију наших представа. Треће, избор ријечи „пучина“ остварује једну сугестију пространства коју друге ријечи из истог парадигматског низа немају и која се појачава у комбинацији са ријечима „плаิва̄ спаิва“, јер дужина њихових вокала продужава тај ефекат бескраја који - на чисто семантичком нивоу - постиже прва ријеч стиха. На тај начин, цјелина израза има своју вриједност само на основу својих дијелова, али и њени дијелови вриједе само на основу своје улоге у тој цјелини. А то су односи које је понекад значајно проучавати, како бисмо разумјели и ефекат цјелине пјесничког израза и функције појединих његових елемената у тој цјелини. (Lešić 1979: 175-176).

Избор се, дакле, односи не само на селекцију него и на комбинацију језичких јединица. А однос између иза- 
бране и неизабраних јединица на парадигматској оси не може бити однос потпуне синонимије, јер структуралистички принцип релационог идентитета језичког знака, односно вриједности језичког знака, искључује могућност постојања праве синонимије ${ }^{2}$. Зато је врло чудно да се један од највећих, готово хорских, приговора теорији стила као избора односио на критику става да избор претпоставља избор између јединица које „казују исту ствар“ (в. нпр. Vuković 2000: 33-34; Juvan 2011: 193-200). Зато не треба да чуди духовита корекција Антоана Кампањона - која се, друкчије формулисана, сусреће и код других аутора (нпр. С. Улмана), а која из перспективе структуралне теорије представља откриће „топле воде“ - да не постоји „више начина да се каже иста ствар“, него да „постоји више начина да се каже скоро иста ствар“ (Vuković 2000: 34). Jep, свака стилистичка варијанта самим тим што је варијанта нужно искључује апсолутну синонимност с било којом

2 Ако нпр. желимо да одредимо структуру скупа елемената АУТО, КАМИОН, ВОЗ и ВЛАК, онда ћемо принципом релационог негативног идентитета „ауто“ идентификовати као оно што није ни „камион“ ни „воз“ ни „влак“; „камион“ ће бити оно што није ни „ауто“ ни „воз“ ни „влак“. Принципом релационог негативног идентитета не могу се, међутим, дефинисати ни „воз“ ни „влак“, јер се „воз“ и „влак“ могу релационо идентификовати само према „ауту“ и „камиону“ („воз/влак“ је оно што није ни „ауто“ ни „камион“), али се релационо не могу идентификовати један према другом, јер „воз“ не можемо одредити као оно што није „влак“, ни обрнуто. То је зато што „воз“ и „влак“ као синоними заузимају исто мјесто у систему, и да би могли ступити у релационе вриједносне односе морају изгубити статус синонима, или тако што ће имати различиту територијалну дистрибуцију, и тако искључити припадност истој структури, или пак тако што ће се „десинонимизирати“ и тако чинити елементе исте структуре. У супротном, употреба таквих синонима у истом исказу доводи до његове таутологичности или плеонастичности. 
другом варијантом. Осим тога, стилски избор се не може посматрати само из перспективе субјекта који пише, тј. писца ${ }^{3}$. Стилски избор није мање значајан ни за читаоца, будући да он „читаоцу/читатељки на основу поређења датог елемента/модела с једним од нереализованих опција конотира дискурзивне контексте у којима се тај у којима се тај елемент/модел појављује чешће или приметније“ (Јуван 2011: 199).

Парадигматски и синтагматски избор међусобно су условљени. Наиме, „сваки текст је резултат низа избора у оквиру два различита схватања те речи. Бирамо сваки елемент парадигматске осе и могућности синтагматског система. Сваки следећи избор је у бити ограничен већ учињеним изборима, али не у тој мери да први потпуно укида следеће“ (Majenova 2009: 351).

Посебно је тај избор на специфичан начин међуусловљен у остварењу поетске функције језика. По Јакобсону, наиме, „поетска функција пројектује принцип еквивалентности из осе селекције у осу комбинације“ (Jakobson 1966: 296). То заправо значи да се пишчев однос према употреби језичких јединица у умјетничком тексту битно разликује од односа онога који те исте језичке јединице употребљава у свакодневном језику. Поетски текст треба увијек да носи нову поетску информацију. На вриједност поетске информације можемо примијенити основно правило теорије информација да је количина информације тим већа што је предвидљивост појављивања неког елемента мања, из чега происходе два нужна закључка: а) да је количина информације већа уколико нека језичка јединица или

3 На што нпр. упућује дефиниција стила П. Гироа (1964: 83): „Стил је аспект исказаног који произлази из избора средстава израза одређеног природом или интенцијом лица које говори или пише“. 
конструкција има већи број изразних могућности, и 2) да је информација равна нули ако је предвидљивост потпуна (уп. Jović 1985: 67-69). Томе је сагласна и експресивна Бартова констатација: „Мучнина се јави чим се свеза између двију важних ријечи сама по себи разyмије“ (Barthes 2004: 136). Умјетнички текст по својој суштини мора искључити ткање које за резултат има нулту информацију. Jер, „Текст значи Ткање, али док смо до сада то ткање увијек узимали као производ, готови вео иза којега се налази више или мање скривен смисао (истина), сада истичемо у ткању ону генеративну идеју коју текст себи ствара, изграђује кроз сталан преплет. [...] Да волимо неологизме, могли бисмо теорију текста одредити као хифологијy (hyphos јест ткање и паукова мрежа)“ (Barthes 2004: 152). Иако је аутор „онај који генерира књижевни текст“, по мишљењу структуралних теорија прве половине XX вијека (руског формализма, феноменолошког приступа или пак „нове критике“), на аутора се „у тумачењу текста не треба освртати“ (Barthes 2004: 19). Те су се школе и/ или теорије усмјериле на изучавање књижевног текста као умјетности ријечи и његових иманентних језичких особина које указују на оно што је у тексту „књижевно“, а то су: поступак, форма, стил и структура. У таквом приступу „аутор се отпушта као ирелевантан судионик у нашем сусрету с текстом“ (Lešić 2015: 9). То најбоље потврђује чувени оглед Смрm аутора (1967) Ролана Барта, у коме се умјесто аутора као творца текста у први план ставља читалац као његов тумач. Барт сматра да текст своје значење добија тек у сусрету с читаоцем, тако да „Текст не ствара Аутор, него Читатељ“, при чему је „циљ књижевног дјела [књижевности као дјела] да читатеља учини не конзументом већ произвођа- 
чем текста“ (Lešić 2015: 44). Без читаоца нема дјела ${ }^{4}$, па читалац тако постаје најзначајнија, ако не и једино значајна, компонента у тријади аутор-дјело-читалац. Јер „свако уметничко дело оправдава своје постојање једино ако у другим људима изазове извесне психичке потресе. Оно је 'језик споразумевања' између ствараоца и других људи, а механизам тог 'језика' састоји се од неухватљивог ткања између уживаоца и дела [...]. Рођено, уметничко дело отцепљује се од свог творца и постаје му страно. Биће својина других ако нађе одјека у њима; у супротном, уметност не постоји“ (Pavlović 2018: 40-41).

Везивање тумачења књижевног дјела само за читаоца доводи, како је то добро уочио 3. Лешић, не само до угрожавања него чак и негирања предмета саме „књижевне критике“, а то је „да тумачи оне облике дискурса које називамо 'књижевна дјела'. Јер, ако би се критика искључиво оријентирала на 'структуру читатељског искуства', не би ли онда дошла у ситуацију да не тумачи текстове, већ да умјесто њих тумачи њихова тумаченьа?" (Lešić 2015: 77-78).

Зато свеобухватно тумачење књижевног текста није могуће везати нити искључиво за сам језик књижевног текста, нити искључиво за самог аутора, нити искључиво за самог читаоца. Уосталом, у литератури је већ уочено да читаоцу књижевно дјело може бити повод за враћање аутора у центар анализе, за његову надређеност самоме дјелу. Јер, чим дјело постане познато, посебно још ако постане врло познато, читаоци почну да се питају: Ко је он, аутор?

4 „Без континуираног активног учешћа Читатеља - читања и поновног читања - не би ни било књижевног дјела.“ (Lešić 2015: 48) 
Дело ће нам постати схватливо тек када упознамо живот неговога твориа - то је лозинка свакојаког јуришања на уметникову интиму. Ко је он? Шта је он? Како је живео и шта је радио? - постаје временом толико важно, да у шуми питања и одговора, психолошких анализа, медицинских хипотеза, етичких и философских класификација и биографских претпоставки дело постепено одлази у други план. Данас се исувише говори о ауторима, данас се њихове настраности, болести, усамљености и јади уздижу на пиједестал прометејства и апостолског значаја. Дело се не тумачи својим особеностима и својом снагом, већ особеностима ауторовог живота. [истицања су у тексту аутора] (Pavlović 2018: 62-63).

Да закључимо. Овдје проведена анализа потврдила је мишљење да „најбитнији и најпознатији појам везан за стил јесте појам избора који претпоставља да се исти садржај може изразити на неколико начина“ (Majenova 2009: 344). Откако се о умјетничком тексту расправља, много прије него што је и створен сам термин стилистика ${ }^{5}$, говорило се о критеријуму избора језичких средстава, и то чешће као саприсутном него као доминантном критеријуму анализе умјетничког текста. Већ је уочено да „сви стилски предлози настали на основу структурне лингвистике садрже појам избора експлицичте или имплицичес (Majenova 2009: 338). Томе треба додати да сви предструктуралистички приступи умјетничком тексту увијек, по правилу имплицитно, садрже и појам избора. И то од најстаријих времена. Још од времена античке реторике као теорије доброг

5 Сам термин стилистика први пут је употријебио њемачки пјесник Новалис (1772-1801) крајем 18. вијека, и то 1799. године, стављајући лексему стилистика као алтернативу термину реторика у називу дјела Stilistik oder Rhetorik (Стилистика или реторика). 
бесједништва. Реторика је у античком времену имала пет дијелова: 1) инвенцију (inventio) или проналажење, 2) диспозицију (dispositio) или распређивање, 3) елокуцију (elocutio) или израз и стил, 4) меморију (memoria) или памћење, и 5) акцију (actio) или излагање говора. Управо елокуција подразумијева принцип избора, јер јој је циљ био да изабрани и осмишљени садржај говора заодјене у одговарајуће ријечи, да га изрази језиком. Тако је понуђен велики списак (инвентар) начина на који се може побољшати естетска или изражајна вриједност говорења. А међу тим начинима доминирале су реторичке или стилске фигуре. Реторичко је учење имало битног утицаја и на прве приручнике о стилу.

А први антички приручник о стилу, онај која се приписује Деметрију, разликују - прије свега на основу критеријума избора типа језичких јединица и типа реченице - четири врсте стила: једноставни, узвишени, углађени и силовити (Demetrije 1999: 24-42). У античком периоду, и то у Аристотеловом времену и времену његових непосредних насљедника, била је, међутим, много познатија трочлана подјела стилова: на високи, средњи и ниски стил. А „подела на високи, средњи и ниски стил ослањала се на разликовање коришћених језичких облика, на степен њиховог богатства и необичности“" (Majenova 2009: 323). Осим тога у Аристотелово вријеме била је врло раширена, протежући се чак до краја средњег вијека, и двоврсна подјела стила, и то на: а) атицистички стил и б) азијански стил. Атицисти су инсистирали на јасноћи као основном критеријуму стила и на употреби општег грчког језика (koine), док за азијанисте „необичност, а не јасноћа постаје мерило савршеног изражавања“" (Majenova 2009: 327-328). 
Све наведено показује да се о стилу као умијећу изналажења изражајних средстава и стилистичких поступака, који су по правилу на неки начин девијантни у односу на изразе свакодневног језика - расправљало од античких времена до данас. И да је теорија стила као језичког избора најраширенија и најпримјењиванија од свих других књижевнокритичких и стилистичких теорија. А њену суштину одражавају три појмовне метафоре: 1) КЊИЖЕВНИ ТЕКСТ ЈЕ ГОЗБА, 2) ЈЕЗИК ЈЕ ТРПЕЗА И 3) КЮИЖЕВНИ ТЕКСТ ЈЕ УЖИТАК/ УЖИВАњЕ. Те три појмовне метафоре имплицитно потврђују да се књижевно дјело једино може схватити и анализирати као дијалектичко јединство ПИСЦА, ЈЕЗИКА и ЧИТАОЦА.

\section{Извори и литература}

Barthes, Roland. Užitak u tekstu / Varijacije o pismu. Zagreb: Meander, 2004.

Vuković, Novo. Putevi stilističke ideje, Podgorica-Nikšić: Jasen, 2000.

Giro, Pjer [Pierre Guiraud]. Stilistika. Sarajevo: Veselin Masleša, 1964.

Demetrije. O stilu. Zagreb: ArTresor naklada, 1999.

Doležel, Lubomir. Poetike Zapada. Beograd: Službeni glasnik, 2013.

Eko, Umberto. O književnosti. Beograd: Vulkan, 2015. Jakobson, Roman. Lingvistika i poetika. Beograd: Nolit, 1966. Jović, Dušan. Jezički sistem i poetska gramatika, Beograd: BIGZ, Priština: Jedinistvo, 1985.

Juvan, Marko. Nauka o književnosti u rekonstrukciji. Beograd: Službeni glasnik, 2011.

Kaler, Džonatan. Sosir - osnivač moderne lingvistike. Beograd: BIGZ, 1980. 
Klikovac, Duška. Metafore u mišljenju i jeziku. Beograd: Biblioteka XX vek, 2004.

Lešić, Zdenko. „Pojam 'izbora' kao instrument analize stila“. Izraz, XV/1 (Sarajevo) 1971. 18-30.

Lešić, Zdenko. Jezik i književno djelo. III izdanje. Sarajevo: Zavod za udžbenike, 1979.

Lešić, Zdenko. Saga o autoru. Sarajevo - Zagreb: Synopsis, 2015. Majenova, Marija Renata. Teorijska poetika. Beograd: Službeni glasnik, 2009.

Pavlović, Živojin. O odvratnom: o umetnosti, o individui, o mnoštvu. Čačak: Gradac K, 2018.

Petrović, Svetozar. Nauka o književnosti. Beograd: Službeni glasnik, 2009.

Речник српског језика. Нови Сад: Матица српска, 2007.

Stanojević, Mateusz-Milan. „Konceptualna metafora u kognitivnoj lingvistici: pregled pojmova“. Suvremena lingvistika, 35. (Zagreb) 2009. 339-371.

Šarić, Ljiljana. Prostor u jeziku i metafora: Kognitivnolingvističke studije o prefiksima i prijedlozima. Zagreb: Naklada Jesenski i Turk, 2014. 
Miloš M. Kovačević

\section{STILISTIC FEAST IN LITERATURE}

The subject of the paper is the analysis of the literary style theory as a choice between different possibilities that makes available to each speaker, and consequently to every writer, with different stylistic variants. This analysis has a theory of conceptual metaphor for the starting point.

It has been shown about that style, as the art of finding expressive means and stylistic practices, which, as a rule, is in some ways deviant from expressions of everyday language - has been discussed since ancient times to the present.

The essence of style theory, as a choice, is reflected in three conceptual metaphors: 1) LITERAL TEXT IS A FEAST, 2) LANGUAGE IS TABLE, and 3) LITERAL TEXT IS A PLEASURE / ENJOYMENT. These three conceptual metaphors implicitly confirm that literary work can only be understood and analyzed as the dialectical unity of the WRITER, LANGUAGE and READER. 